\title{
Measurement of Burnout in university professors during COVID-19
}

\section{Medición del Síndrome de Quemarse por el Trabajo en profesores universitarios durante el COVID-19}

MAY-GUILLERMO, Erika Guadalupe $\dagger$, VELASCO-CASTELLANOS, Jorge, ARIAS- GALICIA, Luis Fernando and DE LA CRUZ-MAY, Samuel*

\author{
Instituto Tecnológico Superior de la Región Sierra, México \\ Universidad Autónoma del Estado de Morelos \\ Universidad Intercultural del Estado de Tabasco
}

ID $1^{\text {st }}$ Author: Erika Guadalupe May-Guillermo / ORC ID: 0000-0001-5403-9849, Researcher ID Thomson: W-4393-2019, CVU CONACYT ID: 366439

ID $1^{\text {st }}$ Co-Author: Jorge Velasco- Castellanos/ ORC ID: 00-0002-6034-6199, CVU CONACYT ID: 865655

ID $2^{\text {nd }}$ Co-author: Luis Fernando Arias- Galicia / ORC ID: 0000-0001-5371-3555, CVU CONACYT ID: 201

ID $3^{\text {rd }}$ Co-Author: Samuel de la Cruz-May / ORC ID: 0000-0001-9180-6349, Researcher ID Thomson: ABD-3123-2020, CVU CONACYT ID: 862273

DOI: $10.35429 / J H R T .2021 .19 .7 .13 .20$

Received: March 30, 2021; Accepted June 30, 2021

\begin{abstract}
The COVID-19 pandemic has led university professors to use new work modalities as demands exceed the response capacity, putting their occupational health at risk. This work provides the preliminary results of an ongoing investigation whose purpose is to determine the presence of Burnout that may be experienced by university professors in the State of Tabasco, Mexico, as a consequence of the adaptations they have made to continue working during the health contingency caused by the SARS-CoV-2 virus. In relation to the methodology, it is a descriptive, cross-sectional and quantitative research, which uses the survey as a data collection technique through an online form. The main contribution of this work is to provide indicators on occupational health that facilitate decision-making by educational authorities regarding the management of teaching staff working in Higher Education Institutions.
\end{abstract}

Burnout, Teachers, Occupational Health

\section{Resumen}

La pandemia por COVID-19 ha propiciado que los profesores universitarios utilicen nuevas modalidades de trabajo cuyas exigencias superan la capacidad de respuesta, poniendo en riesgo su salud ocupacional. El presente trabajo proporciona los resultados preliminares de una investigación en proceso cuya finalidad es determinar la presencia del Síndrome de quemarse por el Trabajo que pudieran estar experimentando los profesores universitarios en el Estado de Tabasco, México, como consecuencia de las adaptaciones que han realizado para continuar laborando durante la contingencia sanitaria provocada por el virus SARS-CoV-2. En relación con la metodología, se trata de una investigación descriptiva, transversal y cuantitativa, que emplea como técnica de recopilación de datos a la encuesta mediante un formulario en línea. La principal contribución de este trabajo es proporcionar indicadores en materia de salud ocupacional que faciliten la toma de decisiones a las autoridades educativas respecto a la gestión del personal docente que labora en las Instituciones de Educación Superior.

Salud ocupacional, Síndrome de Quemarse por el Trabajo, Docentes

Citation: MAY-GUILLERMO, Erika Guadalupe, VELASCO-CASTELLANOS, Jorge, ARIAS- GALICIA, Luis Fernando and DE LA CRUZ-MAY, Samuel. Measurement of Burnout in university professors during COVID-19. Journal of Human Resources Training. 2021, 7-19: 13-20

*Correspondence to Author: (email: chinosix@ hotmail.com)

$\dagger$ Researcher contributing first Author 


\section{Introduction}

The COVID 19 pandemic has been an unprecedented phenomenon in the current age of knowledge with negative effects on different sectors of society (Economic Commission for Latin America and the Caribbean [ECLAC] \& the United Nations Educational, Scientific and Cultural Organization [UNESCO], 2020). These effects have been the subject of interest in different research (Alvarez \& Harris, 2020; Bueno Ferrán \& Barrientos-Trigo, 2020; Bueno \& Barrientos, 2020; Kim \& Asbury, 2020).

In economic terms, international organizations have applied measures and strategies in order to mitigate the effects of COVID-19; However, in the educational field, protection strategies have not received the same attention(Miguel, 2020).

On a regular basis, teaching activity is characterized by facing different challenges that generate an environment of uncertainty and fear, which produces the feeling of lack of control in the face of such eventualities and possible emotional imbalances, influenced by the environment in which they have lived.(MolinaMendoza \& Amador-Velázquez, 2015).

In Mexico, because of the arrival of the pandemic caused by the SARS-CoV-2 virus, many of these challenges have intensified, especially in light of the provisions of the health and educational authorities, who 'through the agreement number $02 / 03 / 20$ published in the DOF dated March 16, 2020 they established that from March 23 to April 17, 2020 classes would be suspended in schools of all levels in Mexico as a preventive measure to reduce the impact of the spread of COVID-19 in the national territory (Agreement Number 02/03/20, 2020).

Subsequently, on March 30, 2020, the agreement number 03/06/20 is issued by which the Secretary of Public Education (SEP) extends the time of suspension of classes, considering as a new period from March 23 to April 30, 2020(Agreement Number 06/03/20, 2020). To conclude the 2019-2020 school year and continue with 2020-2021, the implementation of emergency education was used remotely, so that the student population had access to education from their homes (INEGI, 2021).
This new format forced a change in the teaching-learning environments, therefore, the houses had to be reconfigured so that the members of the student community could carry out their activities.

In this way, educational institutions and their actors were forced to change the paradigm of considering face-to-face education as the main source of training and knowledge transfer and opening up new formats to enable emergency solutions to the crisis caused by the COVID-19 in education (Garcia, 2021).

However, working under these new schemes revealed the limitations presented by the Mexican educational sector. Among these are: weak connectivity, lack of electronic devices and insufficient knowledge about the use of technology exhibited by a large part of the student community (Magallanes \& De Ávila, 2020). At the higher level, teachers had to reinvent their educational practices by resorting to technological means such as virtual platforms, email, landline, cell phone, Facebook, Instagram, Twitter, WhatsApp, institutional web pages, among others (ECLAC \& UNESCO, 2020). Unfortunately, not all teachers had the competencies to work in virtual environments, therefore, it was necessary to train either through institutional channels or independently to achieve the transition from face-to-face to virtual classes.

The adjustments made by the teachers working at home generated that in some cases, the responsibilities and demands exceeded the response capacity; Meanwhile, other teachersdid manage to be resilient to the challenges of the virtual modality of education (Garcia, 2021). Teachers overwhelmed by the challenges caused by COVID-19 are more susceptible to experiencing psychosocial problems such as emotional exhaustion, overwhelm and stress (ECLAC \& UNESCO, 2020).

In this regard, the International Labor Organization (ILO) (2020) sustains the existence of various psychosocial factors with consequences affecting people working from their homes, as in the case of university teachers, these factors being listed below:

$\begin{array}{ll}- & \text { Isolation } \\ - & \text { Excessive working hours }\end{array}$ 
- $\quad$ Blurring of the lines between work and family life

- Multiple burdens (job responsibilities (preparing classes, ensuring proper connections, and following up with students in various formats), household chores, caring for family members and teachers for their children, etc.

- $\quad$ Domestic violence

- $\quad$ Frustration generated by not being a digital native and having to adapt to new contexts.

- $\quad$ Boredom and frustration.

The need to adjust to the conditions of distance education has generated responsibilities and demands on the teaching staff, which significantly increased the time to prepare classes, ensure adequate connections and follow up with their students in different formats. (Human Capital Factor, 2020).

Faced with this situation, an investigation with a quantitative approach was proposed in order to identify whether, in the context described, education personnel in the State of Tabasco are being affected by the harmful effects of these changes. The objective of this work is to present the preliminary results of this research in order toto determine the presence of the Syndrome of being burned by Work which university professors in the State of Tabasco, Mexico could be experiencing, as a consequence of the adaptations made to continue working during the health contingency caused by the SARS-CoV-2 virus.

\section{Theoretical framework}

In this section the theoretical aspects of the variable under study will be located, for a better understanding of it.

\subsection{Burnout Syndrome}

The term Burnout is the translation and expansion into Spanish of the term Burnout, carried out by Gil-Monte (2005), being a phenomenon whose research began in the United States in the early 70s, to explain the process of deterioration in care and professional attention to users of health organizations, who are the most likely to suffer this deterioration (Soto et al., 2017).
According to Maslach (2009) cited by Millán and D'Aubeterre, the burnout "It is a psychological syndrome that involves a prolonged response to chronic interpersonal stressors at work" (Millán \& D'Aubeterre, 2012). This syndrome arises as a response to chronic stress related to occupational psychosocial risks, and should not be confused with stress as it is part of daily life (Muñoz \& Velásquez, 2016).

Burnout is more conducive to those professionals who provide services such as education, health and social service, whose object of work is people (Ortega et al., 2004). In this sense, Camacho et al. (2021) found that in Ecuador $95 \%$ of university professors manifest emotional fatigue and $54 \%$ depersonalization, thus corroborating the existence of Burnout.

\subsection{Models of burnout syndrome}

The most important references in the study of this syndrome refer to Freudenberg, Maslach, Pines and Gil-Monte; being the first the pioneer and almost an obligatory reference for the other studies(Díaz \& Gómez, 2016).

\section{a) Maslach and Jackson Multidimensional Model (MBI-HSS)}

It is the most approached and developed within the clinical-hospital setting, through the MBIHSS (Human Services Survey) inventory and from there other models have emerged, as well as the incorporation of the measure of psychological well-being as a divergent criterion of the Latin American validation of the MBIGS(Millán \& D'Aubeterre, 2012).

According to this model, SQT can be described in the following phases: emotional exhaustion, depersonalization and cynicism. In the first, excessive ambition is present, making the person work harder, ending in fatigue until abandoning their own needs, giving entry to the second phase, depersonalization that protects the worker from disappointment and exhaustion, involving cynical attitudes and feelings, and the last phase that is cynicism related to changes in behavior, anxiety, addiction, despair, little meaning to life which puts it at risk(Aguirre \& Quijano, 2015). 


\section{b) Gil-Monte's Burnout Model (CESQT)}

The Spanish author Gil-Monte (2005) proposes this model as burnout syndrome (CSQT). In this model, Burnout is made up of four factors: Enthusiasm about work, Exhaustion, Indolence and Guilt (Arquero \& Donoso, 2013).

\section{c) Existential Causal Model of Burnout}

The Existential Causal Model of Burnout also stands out, which has a motivational character, starting from the basic assumption that only highly motivated individuals can burn out. That is, people look for an existential meaning and when they do not find it at work, the feeling of failure appears(Díaz \& Gómez, 2016).

\subsection{Characteristics of people with burnout}

Burnout is more conducive to those professionals who provide services such as education, health and social service, whose object of work is people (Ortega et al., 2004).

Paine(1982) recognizes that there are five categories that exhibit the characteristics of people with TQS, which are described below.

a. Physical symptoms: excessive fatigue, physical exhaustion, muscular ailments, and functional alterations in various parts of the body.

b. Excessive behaviors: abundant consumption of substances that trigger other risk behaviors.

c. Problems of emotional adjustment: emotional exhaustion, paranoia, depression and various fears.

d. Alteration of interpersonal relationships: inability to maintain good communication with coworkers, increased conflicts and apathy to serve users both internal and external to the organization.

e. Attitudinal symptoms and changes in the values and beliefs of the individual: emergence of feelings of frustration and failure.

For his part, Gil-monte (2005) found in a study with nursing professionals some outstanding symptoms that characterized burnout, which are a consequence of cognitive, affective, attitudinal, behavioral and physical factors, which are presented in table 1.

\subsection{Method}

This work provides the preliminary results of an applied, descriptive, cross-sectional and quantitative research, the objective of which is to determine the presence of the burnout syndrome at work, which university professors in the State of Tabasco, Mexico, may be experiencing. as a result of the adaptations they have made to continue working during the health contingency caused by the SARS-CoV-2 virus.

\begin{tabular}{|c|c|c|c|}
\hline Cognitive & $\begin{array}{l}\text { Affective- } \\
\text { Emotional }\end{array}$ & Attitudinal & $\begin{array}{c}\text { Other } \\
\text { Symptoms }\end{array}$ \\
\hline $\begin{array}{l}\text { Underestimate } \\
\text { work } \\
\text { Inability to } \\
\text { perform tasks. } \\
\text { Thinking that } \\
\text { you can't cover } \\
\text { everything. }\end{array}$ & $\begin{array}{l}\text { Nervousness } \\
\text { Irritability mood } \\
\text { Bad misgust Anger } \\
\text { Disgustran } \\
\text { Frustration } \\
\text { Aggression } \\
\text { Disenchantment } \\
\text { Overwhelmed } \\
\text { Sadness } \\
\text { Depression } \\
\text { Emotional } \\
\text { exhaustion } \\
\text { Anguish }\end{array}$ & $\begin{array}{l}\text { Discouragement } \\
\text { to work Apathy } \\
\text { Iresponsibility } \\
\text { Intolerance } \\
\text { Impatience } \\
\text { Complain about } \\
\text { everything } \\
\text { Negatively } \\
\text { evaluating } \\
\text { colleagues }\end{array}$ & $\begin{array}{l}\text { Behavioral } \\
\text { isolation Not } \\
\text { cooperating } \\
\text { Answering } \\
\text { badly } \\
\text { Confrontations } \\
\text { Tiredness }\end{array}$ \\
\hline
\end{tabular}

Table 1 Symptoms of TQS. Adapted from Gilmonte(2005)

\subsection{Data collection technique and participants}

The data collection technique was a survey using an online form. Initially, the authorization of the institutional authorities was requested and later the professors were invited to participate voluntarily. The demographic characteristics of the participants are shown in Table 2.

\begin{tabular}{|l|l|r|}
\hline \multicolumn{2}{|c|}{ Variable } & \multicolumn{1}{c|}{$\%$} \\
\hline \multirow{2}{*}{ Gender } & Female & $53 \%$ \\
\cline { 2 - 3 } & Male & $47 \%$ \\
\hline estatus & Lived with a partner & $71 \%$ \\
\hline Level of & Without a partner & $29 \%$ \\
education & Technician & $1 \%$ \\
& Bachelor's Degree & $33 \%$ \\
& Master's Degree & $52 \%$ \\
Length & PhD & $14 \%$ \\
\hline \multirow{2}{*}{ of } & $<1$ year & $3 \%$ \\
& From 1 to 5 years & $22 \%$ \\
& From 6 to 10 years & $19 \%$ \\
& From 11 to 15 years & $22 \%$ \\
& From 16 to 20 years & $19 \%$ \\
& 21 to 25 years & $11 \%$ \\
Sector & More than 25 years & $4 \%$ \\
\hline & Public & $31 \%$ \\
& Private & $14 \%$ \\
\hline
\end{tabular}

Table 2 Participants profile Source: Self Made 


\subsection{Instrument}

The instrument applied was the CESQT used by Gil-Monte to measure burnout (2009) because this instrument improves the psychometric properties of others that have been used for this purpose, since it emerges from a theoretical model. It also adds the variable guilt, promoting a better understanding of the burnout construct and provides a more appropriate cultural approach to the Latin American context (Olivares-Faúndez et al., 2019).

Regarding the reliability of the instrument, adequate values were reached in the Cronbach's alpha statistic according to Landero and González (2016), only the indolence dimension was slightly low (see Table 3 ).

\begin{tabular}{|l|r|}
\hline \multicolumn{1}{|c|}{ Dimension } & Cronbach's alpha \\
\hline Enthusiasm about work & 0.86 \\
\hline Exhaustion & 0.88 \\
\hline Indolence & 0.68 \\
\hline Guilt & 0.86 \\
\hline
\end{tabular}

Table 3 Instrument reliability

Source: Self Made

\subsection{Operationalization of variables}

In the research, the study variables were considered to be the Burnout Syndrome (SQT) and the four dimensions proposed by Gil-Monte (2005), 1) enthusiasm about work, 2) exhaustion, 3) indolence and 4) guilt, which were operationalized according to table 4.

\subsection{Statistical procedure}

The arithmetic means were calculated, as well as the alpha reliability of each of the dimensions considered in the study.

Likewise, the frequencyhistograms were obtained. Initially, the instrument was codified considering the 4 dimensions mentioned in table 3. Likewise, the data obtained were transferred to the statistical software SPSS version 22.0.

\begin{tabular}{|l|l|}
\hline \multicolumn{2}{|c|}{ Variable } \\
\begin{tabular}{|l} 
Enthusiasm \\
about work
\end{tabular} & $\begin{array}{l}\text { It is understood as a cognitive aspect } \\
\text { (considering work as a challenge, as a } \\
\text { personal fulfillment). }\end{array}$ \\
\hline Exhaustion & $\begin{array}{l}\text { It is explained as an affective deterioration } \\
\text { (emotional and physical exhaustion). }\end{array}$ \\
\hline Insólense & $\begin{array}{l}\text { Characterized by the appearance of negative } \\
\text { attitudes and behaviors towards } \\
\text { clients and towards the organization, in the } \\
\text { form of indifferent, cold, distant, and } \\
\text { sometimes harmful behaviors. }\end{array}$ \\
\hline Guilt & $\begin{array}{l}\text { Negative feeling, of remorse resulting from } \\
\text { the belief that a social norm or belief has } \\
\text { been violated or is capable of being violated } \\
\text { and for having committed negative attitudes } \\
\text { and behaviors at work. }\end{array}$ \\
\hline
\end{tabular}

Table 4 Variables operationalization

Source: Made based on Gil-Monte (2005)

\section{Results}

Next, the results of the first advance of the investigation are presented, starting with the descriptive variables of the studied variables that are presented in Table 5.

\begin{tabular}{|l|r|r|}
\hline \multicolumn{1}{|c|}{ Variable } & Half & Standard deviation \\
\hline 1) Enthusiasm about work & 3.31 & 0.58 \\
\hline 2) Exhaustion & 1.75 & 0.85 \\
\hline 3) Indolence & 0.40 & 0.42 \\
\hline 4) Guilt & 0.71 & 0.71 \\
\hline
\end{tabular}

Table 5 Descriptive of the study variables Source: Self Made

For enthusiasm about work dimension, a mean of 3.31 and a standard deviation of 0.58 were obtained (see table 4). Likewise, figure 1 shows the bias of the data to the right: the most repeated answer option is $4=$ Very frequently.

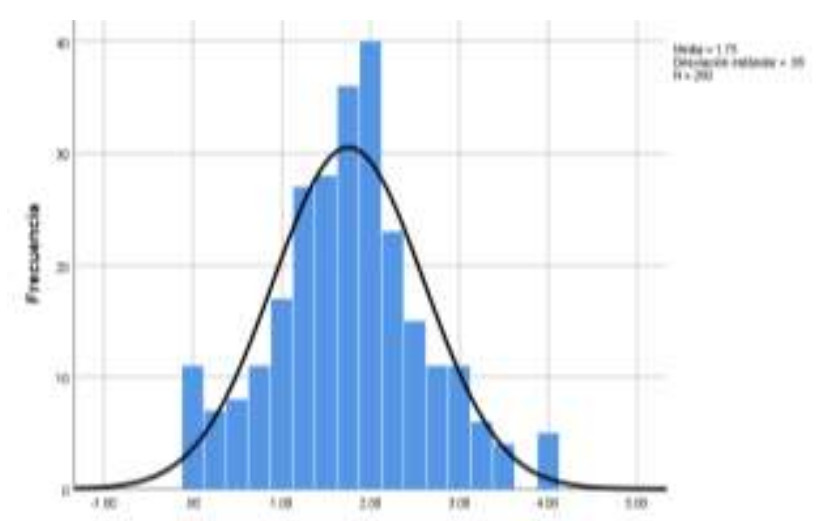

Figure 1 histogram of the dimensión enthusiasm about work

Regarding the dimension exhaustion, a mean of 1.75 and a standard deviation of 0.85 were obtained (see table 4). This was the dimension that registered the greatest variability in the data, the answer option being $2=$ Sometimes the most repeated.

MAY-GUILLERMO, Erika Guadalupe, VELASCO-CASTELLANOS, Jorge, ARIAS- GALICIA, Luis Fernando and DE LA CRUZ-MAY, Samuel. Measurement of Burnout in university professors during COVID-19. Journal of Human Resources Training. 2021 


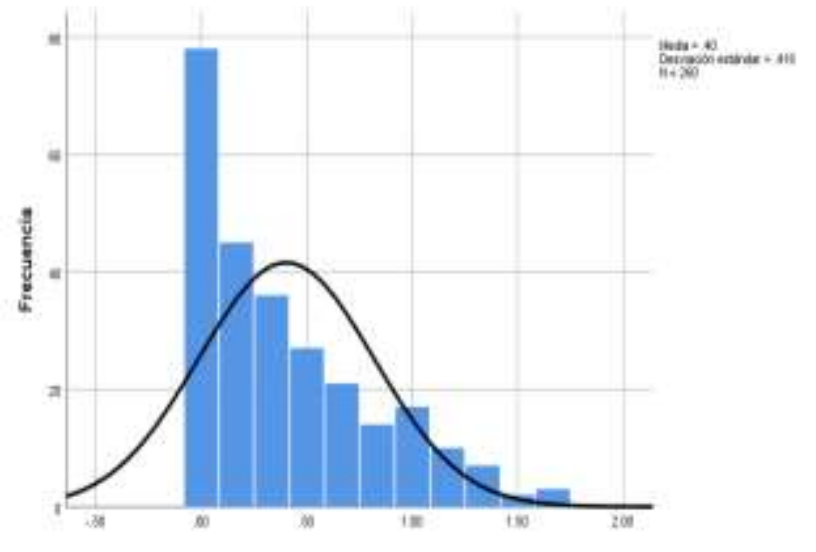

Figure 2 histogram of the exhaustion dimension

The indolence dimension reported a mean of 0.40 and a standard deviation of 0.42 (see table 4). This was the dimension that registered the smallest of the means, but the greatest variability in the data, as can be seen in Figure 3, with the answer option being $.00=$ never, it is the most repeated.

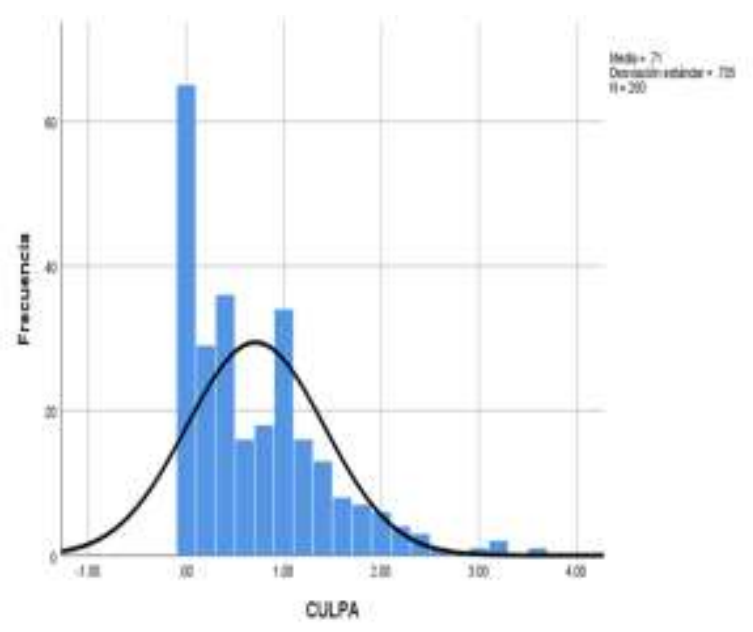

Figure 3 histogram of the Indolence dimensión.

In the guilt dimension, a value of 0.71 was obtained for both the mean and the standard deviation (see table 4), while the answer option $.00=$ never is the most repeated as shown in figure 4 .

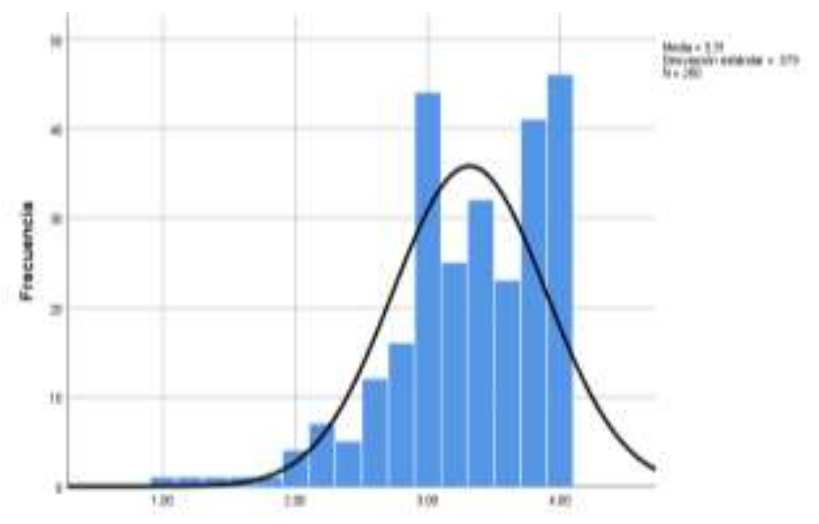

Figure 4 histogram of the Guilt dimensión

\section{Acknowledgments}

We thank the Council of Science and Technology of the State of Tabasco (CCYTET) for the financial support granted for the development of this project, through the Program for the Development of Science, Technology and Innovation of the State.

\section{Conclusions}

The teachers participating in the study show a favorable level of enthusiasm for work. However, it is desirable to stimulate this factor in educational institutions to achieve greater involvement by employees.

Likewise, a low record of the level of Psychic wear, which is a favorable indicator up to the moment in which the study is carried out. However, it is necessary to continue monitoring this factor in order to identify possible cases in a timely manner and attend to them in a timely manner. Similarly, a low manifestation of the level of Indolence was found, as well as Guilt, which denotes the responsibility and ethics with which teachers consider carrying out their academic activities.

It is concluded: despite the adverse conditions faced by teachers during the COVID19 pandemic, they have relied on the protective factor enthusiasm for work, to counteract deteriorating aspects such as mental exhaustion, indolence and guilt, which according to the comments they share teachers in the surveys carried out have achieved by developing new skills and attitudes. In addition, the results indicate the use of resilience to overcome the difficulties imposed by the pandemic. The psychological strength of the members of the sample under analysis is then denoted.

As of the date this document is written, the situation of university teachers regarding their return to the classroom is uncertain. However, the online modality has allowed greater flexibility and use of digital resources to complement face-to-face education, therefore it is suggested to evaluate the relevance of a hybrid model according to the resources in possession of the student community and the existing sanitary conditions(Garcia, 2021). 
The main contribution of this work is to provide indicators on occupational health to facilitate decision-making by educational authorities regarding the management of teaching staff working in Higher Education Institutions. However, it is necessary to expand the population of analysis and evaluate the relationships that the current results could have with some demographic variables of interest.

\section{References}

Agreement number 06/03/20, DOF - Official Gazette of the Federation 8 (2020). https://www.dof.gob.mx/nota_detalle.php?codi go $=5590981 \&$ fecha $=01 / 04 / 2020$

Agreement number 02/03/20, Pub. L. No. 02/03/20, Official Gazette of the Federation 2 (2020).

https://www.dof.gob.mx/nota_detalle.php?codi go $=5589479 \&$ fecha $=16 / 03 / 2020$

Aguirre, AM, \& Quijano, AM (2015). Syndrome due to burns at work and family and work variables of general practitioners in Bogotá. A labor quality strategy. Colombian Journal of Psychiatry, 44 (4), 198-205. https://doi.org/10.1016/j.rcp.2015.05.017

Aguirre Roldán, AM, \& Quijano Barriga, AM (2015). Syndrome due to burns at work and family and work variables of general practitioners in Bogotá. A labor quality strategy. Colombian Journal of Psychiatry, 44 (4), 198205. https://doi.org/10.1016/j.rcp.2015.05.017

Alvarez, R., \& Harris, P. (2020). Covid-19 in Latin America: Challenges and opportunities. Revista Chilena de Pediatria, 91 (2), 179-182. https://doi.org/10.32641/rchped.vi91i2.2157

Arquero, JL, \& Donoso, JA (2013). Teaching, research and burnout: The burnout syndrome in accounting university professors. Revista de Contabilidad-Spanish Accounting Review, 16 (2), 94-105.

https://doi.org/10.1016/j.rcsar.2013.04.001

Bueno Ferrán, M., \& Barrientos-Trigo, S. (2020). Caring for the caregiver: The emotional impact of the coronavirus epidemic on nurses and other health professionals. Clinical Nursing. https://doi.org/10.1016/j.enfcli.2020.05.006
Bueno, M., \& Barrientos, S. (2020). Caring for the Caregiver: The Emotional Impact of the Coronavirus Epidemic on Nurses and Other Health Professionals. Clinical Nursing, 1-8. https://doi.org/10.1016/j.enfcli.2020.05.006

Camacho, R., Gaspar, M., \& Rivas, C. (2021). Burnout syndrome and work stress by covid-19 in Ecuadorian university teachers stress by covid-19 in ecuadorian Burnout syndrome and work university teachers Abstract. Journal of the Community and Health Research Group, 6 (4), 166-177.

http://erevistas.saber.ula.ve/index.php/ógicos/ar ticle/view/17425

ECLAC, \& UNESCO. (2020). Education in times of the COVID-19 pandemic. In Report. https://doi.org/10.5209/GEOP.69137

Díaz, F., \& Gómez, C. (2016). Research on the Burnout Syndrome in Latin America between 2000 and 2010. Psychology From The Caribbean, 33 (1), 113-131.

Human Capital Factor. (2020). Teachers in the pandemic: The challenge of relearning, reorganizing, teaching, caring ... Human Capital Factor. World Of Work. https://factorcapitalhumano.com/mundo-deltrabajo/docentes-en-la-pandemia-el-desafio-dereaprender-reorganizar-ensenar-cuidar/2020/08/

García, L. (2021). COVID-19 and digital distance education: pre-confinement, confinement and post-confinement. IberoAmerican Journal of Distance Education, 24 (1), 9-25. https://doi.org/10.5944/ried.24.1.28080

Gil-monte, PR (2005). The syndrome of Burnout from Work (BURNOUT) An occupational disease in the welfare society (Psychology). Pyramid

Editions. https://www.researchgate.net/publication/26327 6105_Burnout_syndrome_by_work_burnout_A work-

related_sickness_in_the_society_of_well-being

Gil-Monte, PR, Unda, S., \& Sandoval, JI (2009). Factorial validity of the Questionnaire for the Evaluation of the Syndrome of Burning at Work (CESQT) in a sample of Mexican teachers. Mental Health, 32 (3), 205-214. 
INEGI. (2021). Survey to Measure the Impact of COVID-19 on Education (ECOVID-ED) 2020. Technical Note. Second Edition (pp. 1-30). https://www.inegi.org.mx/contenidos/investigac ion/ecovided/2020/doc/ecovid_ed_2020_nota_t ecnica.pdf

Kim, LE, \& Asbury, K. (2020). 'Like a rug had been pulled from under you': The impact of COVID-19 on teachers in England during the first six weeks of the UK lockdown. In British Journal of Educational Psychology (Vol. 90, Issue 4, pp. 1062-1083). https://doi.org/10.1111/bjep.12381

Landero, R., \& González, M. (2016). Statistics with SPSS and Research Methodology (1st ed).

Magallanes, E., \& De Ávila, J. (2020). Initial response by a group of Mexican teachers to the closure of schools due to Covid-19. Journal of the La Salle University Research Center, 14 (53), 11-44. https://doi.org/10.26457/recein.v14i53.2663

Miguel, J. (2020). Higher education in times of pandemic: a view from within the training process. Latin American Journal of Educational Studies, $\quad 50, \quad 13-40$. https://rlee.ibero.mx/index.php/rlee/issue/view/ 177/RLEE LI.3

Millán de Lange, AC, \& D'Aubeterre López, ME (2012). Psychometric properties of the Maslach Burnout Inventory-GS in a Venezuelan multioccupational sample. Journal of Psychology, 30 (1), 103-128. https://doi.org/10.18800/psico.201201.005

Molina-Mendoza, Amador-Velázquez, R.-G. (2015). Burnout syndrome: comparative study between teachers and nurses. Electronic Journal Medicine, Health and Society, 5 (2), 109-120.

Muñoz, AI, \& Velásquez, MS (2016). Workburn syndrome in nursing professionals, Bogotá, Colombia. Journal of the National School of Public Health, 34 (2). https://doi.org/10.17533/udea.rfnsp.v34n2a09

ILO. (2020). Facing the pandemic: guaranteeing health and safety at work (p. 33).
Olivares-Faúndez, V., Arias, F., Peralta, J., Jélvez-Wilke，C., Morales-Gutiérrez，J., \& Riquelme, G. (2019). The role of guilt in the relationship between burnout and absenteeism work in administration and industrial services workers. Interciencia, 44 (3), 147-153. https://www.researchgate.net/publication/33244 8826_The_role_of_guilt_in_the_relationship_b etween_burnout_and_absenteeism_work_in_ad ministration_and_industrial_services_workers

Ortega, C., López, F., \& Universidad, R. (2004). Burnout or syndrome of being burned in health professionals: review and perspectives1. International Journal of Clinical and Health Psychology, 4 (1), 137-160.

Paine, WS (1982). Overview: Burnout stress syndromes and the 1980s. In Job stress and burnout: research theory and intervention perspectives (pp. 11-29). Beverly Hills, CA: Sage.

Soto Fuentes, PE, Barrios Araya, S., \& Molina Muñoz, Y. (2017). Burnout from Work Syndrome and Job Satisfaction as predictors of quality of hospital nursing care. Science and Nursing, 23 (3), 99-111. https://doi.org/10.4067/s0717-

95532017000300099 